Bangladesh J. Plant Taxon. 24(1): 91-105, 2017 (June)

(C) 2017 Bangladesh Association of Plant Taxonomists

\title{
POLLEN MORPHOLOGY AND NUMERICAL ANALYSIS OF TAMARIX L. (TAMARICACEAE) IN EGYPT AND ITS SYSTEMATIC IMPLICATION
}

\author{
Ahmed ElKordy $^{1}$ And Ahmed Faried ${ }^{2}$ \\ Botany \& Microbiology Department, Fac. of Science, Sohag University, 82524, Egypt
}

Keywords: Tamarix; Pollen Morphology; Numerical Taxonomy; UPGMA Cluster; PCO, Egypt.

\begin{abstract}
A palynological and multivariate study of six species of Tamarix L. distributed in Egypt was carried out. Pollen morphology was examined by Light Microscope (LM) and Scanning Electron Microscope (SEM). The systematic study of these species was conducted by means of numerical analysis using UPGMA clustering and PCO analysis based on 33 morphological characters, including life form, vegetative parts, fruits, floral characters, seeds and pollen grains. Pollen grains were found to be monads, radially symmetrical, isopolar, small-sized and homocolpate. Tamarix nilotica can be easily separated from other taxa by its subprolate pollen shape. Two major clades were identified by multivariate analysis of morphological characters; one of them included three species, namely $T$. amplexicaulis, $T$. passerinoides and $T$. macrocarpa. Our results indicate that there is a wide range of morphological similarity among the species of section Polyadenia. The other clade included T. aphylla, T. tetragyna and T. nilotica from section Tamarix and section Oligadenia.
\end{abstract}

\section{Introduction}

Tamarix L. is one of the four genera of Tamaricaceae, and consists of halophytic shrubs and dwarf trees native to Europe, Asia, southern and northern Africa (Baum,1978).The taxonomy of Tamarix is notoriously complex (Bunge, 1852; Zohary, 1972; Baum, 1978; Villar et al., 2014). Most of its members show few distinctive external features (Baum, 1978) and most taxa are difficult to distinguish in the vegetative state (Crins, 1989). Hybridization is considered as one of the most important factors which may play a great role in this taxonomic interference (Rusanov, 1949; Wilken, 1993). The most recent global revision of the genus Tamarix by Baum (1978) includes three featured sections, viz. Tamarix, Oligadenia and Polyadenia, separated primarily by petal length, number of stamens, shape of androecial disk and attachment of filament insertion on the androecial disk. Furthermore, these sections are split into nine series based on several floral and vegetative characters. Intermediate forms have been observed for many characters which are used in identification of taxa within the genus, and these characters usually vary seasonally on the same individual (Rusanov,1949).

Species of Tamarix cannot be identified without the presence of floral and fruit characters (Crins, 1989). According to Baum (1978) and Crins (1989), morphological characters such as life form and growth morphology, leaf characters (vaginate vs. sessile), number of floral parts and morphology of androecial disk can be used for distinguishing certain species. Other characters such as shape of petal and sepal, presence or absence of hairs on the raceme rachis and the nature of filament attachment to the androecial disc are discussed by Gaskin and Schaal (2003). According to Venturella et al. (2007) most taxa of Tamarix L. have more or less the same morphological and ecological similarity, infraspecific variability and teratology of floral elements.

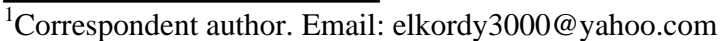

${ }^{2}$ Botany \& Microbiology Department, Faculty of Science, Assiut University, 71515, Egypt.

DOI: http://dx.doi.org/10.3329/bjpt.v24i1.33036
} 
The difficulties in the identification of Tamarix species sometimes give rise to inaccurate descriptions and problems in analytical keys.

Täckholm (1974) reported five species of Tamarix from Egypt, namely T. aphylla, T. tetragyna, T. nilotica, T. amplexicaulis and T. passerinoides Hosni (2000) added new three taxa to the flora of Egypt, viz. T. macrocarpa, T. mannifera and T. arborea. Boulos (2000) in his last issue of Flora of Egypt reduced the number of species to six and treated T. mannifera and $T$. arborea as synonyms of $T$. nilotica. Moreover, he reported T. macrocarpa from Egypt, but still some authors consider T. macrocarpa to be conspecific with Tamarix passerinoides; others treat it as a variety of the latter species. Baum (1978) treated T. mannifera, T. arabica, T. gallica, and T. arborea as separate good species; while Boulos (2000) treated all of them as synonyms of $T$. nilotica. Baum (1978) treated T. meyeri as good separate species, while Boulos (2000) considered it as a synonym of $T$. tetragyna. Concerning $T$. effusa and $T$. deserti, the two species are considered by Baum (1978) and Boulos (2000) as synonyms of T. tetragyna (Table 1).

The objectives of this work are to investigate suitability of pollen morphology for distinguishing Egyptian Tamarix and by using 33 characters, how do multivariate analyses agree with the sectional placement of the genus Tamarix.

\section{Materials and Methods}

Palynological study

Pollen grains examined for Tamarix species in this study were collected from herbarium specimens given in Appendix 1. Pollen grains were acetolized and mounted on a metallic stub in a few drops of ethanol according to methods outlined in Moore et al. (1991). Light microscopy of pollen grains was carried out using an Olympus type BH-2 research microscope. The measurements were based on at least 20 pollen grains per specimen. Photomicrographs were taken under an Olympus photomicroscope microscope. For scanning electron microscopy (SEM), Pollen grains were prepared according to the procedure given by Baum et al. (1970). The specimens were coated with gold in an Apolaron E1100 ion sputtering device, then viewed at 25-30 kv in a JOEL JSM 5300 scanning electron microscope. The means of Polar axis $(P)$ and equatorial diameter $(E)$ were measured and the $P / E$ ratio was calculated over all specimens. The main morphological characters and terminology and concepts of pollen grains are based on Huysmans et al. (2003); Punt et al. (2007); Erdtman (2013).

\section{Multivariate analysis of 33 morphological characters}

Plant materials: The multivariate study is based on herbarium specimens borrowed from the following herbaria: CAI, CAIM, ASTU, W, and SHG. In addition, fresh materials of the most species were collected, field observations were made from several localities in Egypt. Species constituted the OTU (Operational Taxonomic Unit) are presented in Table 3.

In order to broadly sample the morphological variation, the OTUs consist of a number of collections/accessions (either herbarium specimens or fresh material or both) from different localities in Egypt. For some taxa, materials from Egypt were not available or limited, so specimens from other countries were used (OTUs 2 and 4.)

Morphological character observations: Morphological characters and character states scored for plant, seed, and pollen are presented in Table 4. A total of 33 characters were measured on each specimen, comprising 15 quantitative and 18 qualitative characters; 3 of the qualitative characters were scored as binary and the rest were scored as multi-state characters.

Plant morphology, flower and fruit characters: The measurements for all specimens of a taxon were averaged into one OTU scored for each of the characters. OTU scores for quantitative 
characters were averages of measurements of at least 10 specimens (where possible). Because herbarium specimens cannot be considered to be a random sample of species, we followed Wieringa (1999) by calculating the mean of the minimum and maximum measurement of all specimens for species. The complete data matrixes for the Numerical Taxonomy study, including specimen citations are available as appendixes from the Department of Botany and Microbiology, Sohag University, Faculty of Science, Egypt.

Table 1. Synopsis of the Egyptian Tamarix (according to Baum 1978 and Boulos 2000).

\begin{tabular}{|c|c|c|c|c|c|}
\hline \multirow{2}{*}{ No. } & \multirow{2}{*}{ Taxa } & \multicolumn{3}{|c|}{ Baum (1978) } & \multirow{2}{*}{ Boulos (2000) } \\
\hline & & Sect. & Series & Rank & \\
\hline 1. & Tamarix nilotica & \multirow{9}{*}{ Tamarix } & \multirow{4}{*}{ Leptostachyae } & & Good species \\
\hline 2. & T. mannifera & & & Good sp. & \\
\hline 3. & T. arborea & & & Good sp. & \\
\hline 4. & T. arabica & & & Good sp. & Syns. of T. nilotica \\
\hline 5. & T. gallica & & Gallica & Good sp. & \\
\hline 6. & T. aphylla & & \multirow{4}{*}{ Vagianates } & & Good species \\
\hline 7. & Thuja aphylla & & & \multirow{3}{*}{\multicolumn{2}{|c|}{ Syns. of T. aphylla }} \\
\hline 8. & T. orientalis & & & & \\
\hline 9. & T. articulata & & & & \\
\hline 10. & T. tetragyna & \multirow{4}{*}{ Oligadenia } & \multirow{4}{*}{ Anisandrae } & \multicolumn{2}{|r|}{ Good species } \\
\hline 11. & T. meyeri & & & Good sp. & Syn. of T. tetragyna \\
\hline 12. & T. effuse & & & \multirow{2}{*}{\multicolumn{2}{|c|}{ Syns. of T. tetragyna }} \\
\hline 13. & T. deserti & & & & \\
\hline 14. & T. passerinoides & \multirow{3}{*}{ Polyadenia } & \multirow{3}{*}{ Pleiandrae } & \multirow{3}{*}{\multicolumn{2}{|c|}{ Good species }} \\
\hline 15. & T. macrocarpa & & & & \\
\hline 16. & T. amplexicaulis & & & & \\
\hline
\end{tabular}

\section{Data analysis}

Two types of analyses were performed with PAST (Paleontological Statistics Version 3.15) (Hammer et al., 2001). First, we performed a cluster analysis using average taxonomic distance and UPGMA clustering (procedures RHO and HAMMING similarity index) to reduce the effects of different scales of measurement for different characters. Secondly a principal coordinates analysis (PCO) was performed, using the product-moment correlation as a coefficient. The procedure (RHO similarity index) was used to calculate the distance matrix and PCO based on STAND data.

\section{Results}

Pollen grains in Tamarix species are free (monads), tricolpate, prolate to subprolate Pollen grains: in equatorial view to spheroidal in polar view; ranging from 11.92 to $18.56 \mu \mathrm{m}$ in polar axis length, 7.82 to $12.77 \mu \mathrm{m}$ in equatorial diameter. The ratio of polar axis to the equatorial diameter $(P / E)$ is between 1.3 and 1.63; they all have small, fine to coarse reticulate sculpturing grains, luminae polygonal in shape. Apertures are 3 , and simple (Table 2).

All pollen grains of studied species found to be isopolar and radially symmetrical. They are suboblate, oblate sphenoidal, spheridal, prolate, prolate spheroidal and subprotate in shape (Figs 1- 
6). The ratio between the mean polar axis $(P)$ and the mean equatorial diameter $(E)$ can be used to assign the pollen grains to shape classes as follows (Punt et al., 2007).

Pollen grains suboblate when $P / E=0.75-0.875$; Pollen grains oblate spheroidal when $P / E=$ 0.875-1.0; Pollen grains spheroidal when $P / E=1.0$; Pollen grains prolate spheroidal when $P / E=$ 1.1-1.14; Pollen grains subprolate when $P / E=1.14-1.33$; Pollen grains prolate when $P / E=1.33$ 2.0

For each studied species, the mean of polar axis is plotted against the mean equatorial diameter (Fig. 7). Oblate and peroblate grains would lie above this $45^{\circ}$ line, and oblate spheroidal and suboblate above but near this line. Perfectly spheroidal grains must lie along the $45^{\circ}$ line in Fig. 1, with perprolate and prolate grains below this line and subprolate and prolate spheroidal below but near the line. Concerning the studied species, there was a tendency for pollen grains to have a prolate shape in all species examined except $T$. nilotica issubprolate (Fig. 3A). The pollen grains seem to be mostly circular in polar view, often slightly lobed due to sunken colpi.

Pollen grains of studied taxa are comparatively small; the average polar axis value ranges from $11.96 \mu \mathrm{m}$ in T. nilotica to 16.84 in T. passerinoides; the average $E$ value varies from $9.14 \mu \mathrm{m}$ in T. nilotica to $11.41 \mu \mathrm{m}$ in T. aphylla (Table 2). All pollen grains are characterized by simple apertures and are zonocolpate; the colpi are narrow to slit-like after acetolysis, they are usually widest at the equatorial view and gradually narrow towards the poles. The number of colpi is always three.

Pollen grain have the same ornamentation pattern with reticulate tectum, circular to polygonal laminae in shape, 0.46 - $0.91 \mu \mathrm{m}$ in length (Figs 1B-6B).

Table 2. Morphological data of pollen grain characters of genus Tamarix.

\begin{tabular}{|c|c|c|c|c|c|c|c|c|c|}
\hline \multirow{2}{*}{$\begin{array}{l}\text { Sl. } \\
\text { No. }\end{array}$} & \multirow[t]{2}{*}{ Species } & \multicolumn{2}{|c|}{$\begin{array}{c}\text { Polar axis } \\
(\mathrm{P} \mu \mathrm{m})\end{array}$} & \multicolumn{2}{|c|}{$\begin{array}{l}\text { Equatorial axis } \\
(\mathrm{E} \mu \mathrm{m})\end{array}$} & \multirow[t]{2}{*}{$\mathrm{P} / \mathrm{E}$} & \multirow{2}{*}{$\begin{array}{l}\text { Pollen } \\
\text { shape }\end{array}$} & \multirow{2}{*}{$\begin{array}{l}\text { Aper- } \\
\text { ture } \\
\text { no. }\end{array}$} & \multirow{2}{*}{$\begin{array}{c}\text { Surface } \\
\text { ornamen- } \\
\text { tation }\end{array}$} \\
\hline & & Range & Mean & Range & Mean & & & & \\
\hline 1. & T. aphylla & $13.30-18.56$ & 15.91 & $10.11-12.77$ & 11.41 & 1.39 & Prolate & 3 & Reticulate \\
\hline 2. & T. tetragyna & $14.38-17.62$ & 16.23 & 7.82-11.99 & 10.32 & 1.57 & Prolate & 3 & Reticulate \\
\hline 3. & T. nilotica & $11.92-11.99$ & 11.96 & 8.64-9.94 & 9.14 & 1.30 & Subprolate & 3 & Reticulate \\
\hline 4. & T. amplexicaulis & $14.49-16.1$ & 15.54 & $10.71-10.97$ & 10.81 & 1.40 & Prolate & 3 & Reticulate \\
\hline 5. & T. passerinoides & $14.75-17.91$ & 16.84 & $8.92-10.90$ & 10.26 & 1.64 & Prolate & 3 & Reticulate \\
\hline 6. & T. macrocarpa & $14.79-17.10$ & 15.64 & $10.92 \backslash-9.18$ & 10.23 & 1.52 & Prolate & 3 & Reticulate \\
\hline
\end{tabular}

Equatorial diameter $(E)$; Polar axis $(P)$; the ratio between the Polar and Equatorial $(P / E)$

\section{Multivariate analysis of 33 morphological characters}

Cluster analysis

Figure 8 shows the dendrogram of all OTUs studied, clustered by the UPGMA method. The cophenetic correlation of distance matrix and tree matrix was 0.9512 , indicating a good fit of the dendrogram to the distance matrix, see Rohlf (1990) .

Two clades were identified, namely clade A and Clade. Clade A is divided into two subgroups: subgroup (I) comprising $T$. amplexicaulis, and subgroup (II) comprising $T$. passerinoides and T. macrocarpa. Clade B is also divided into two subgroups: subgroup (III) comprising T. nilotica and T. tetragyna, while sub group (IV) comprising only T. aphylla. 

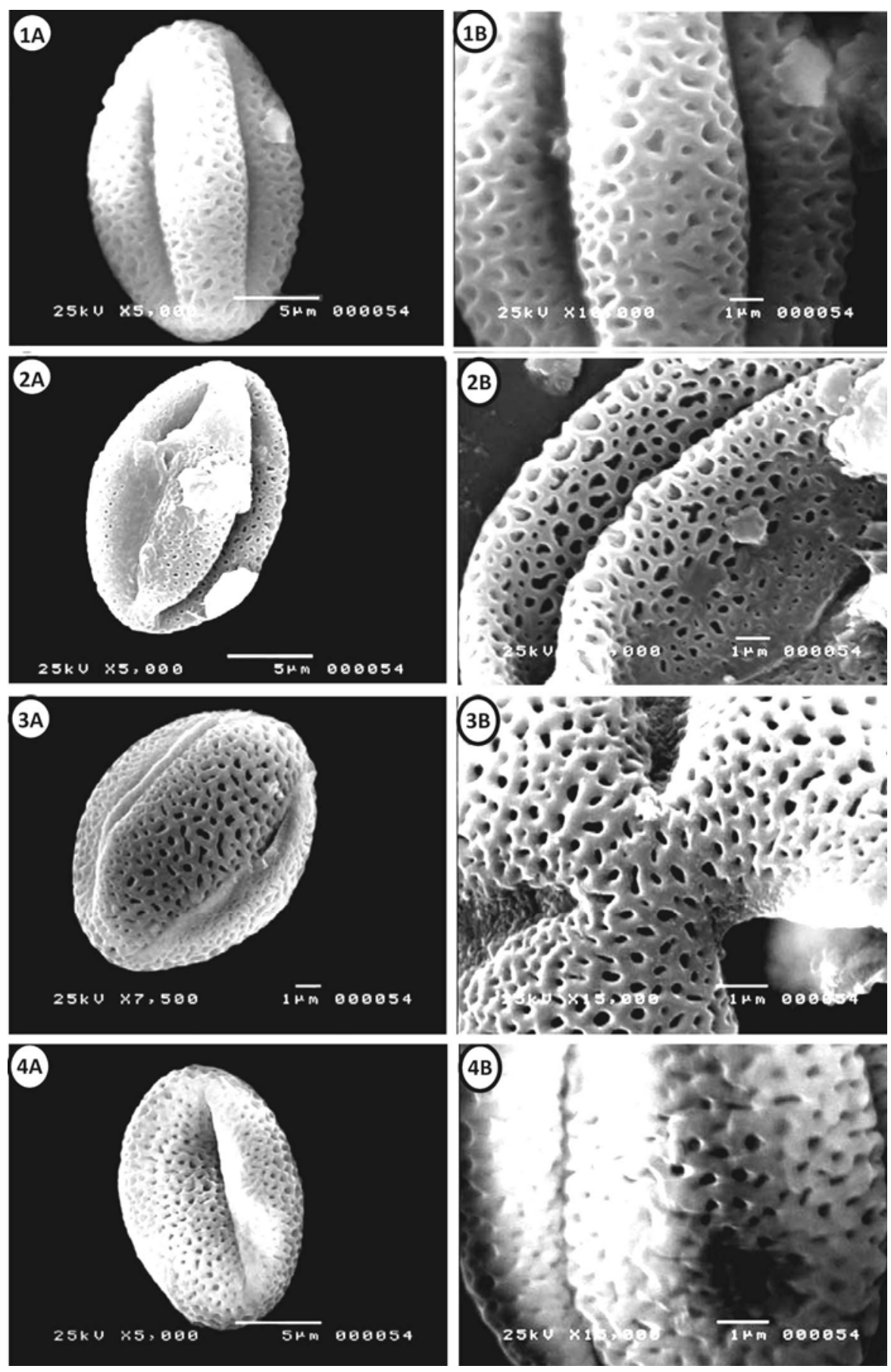

Figs 1-4. Pollen grains photographs of studied species under Scanning electron microscope: A- entire pollen grains; B - enlargement part of pollen grain exine: 1. T. aphylla, 2. T. tetragyna, 3. T. nilotica, 4. T. amplexicaulis. 

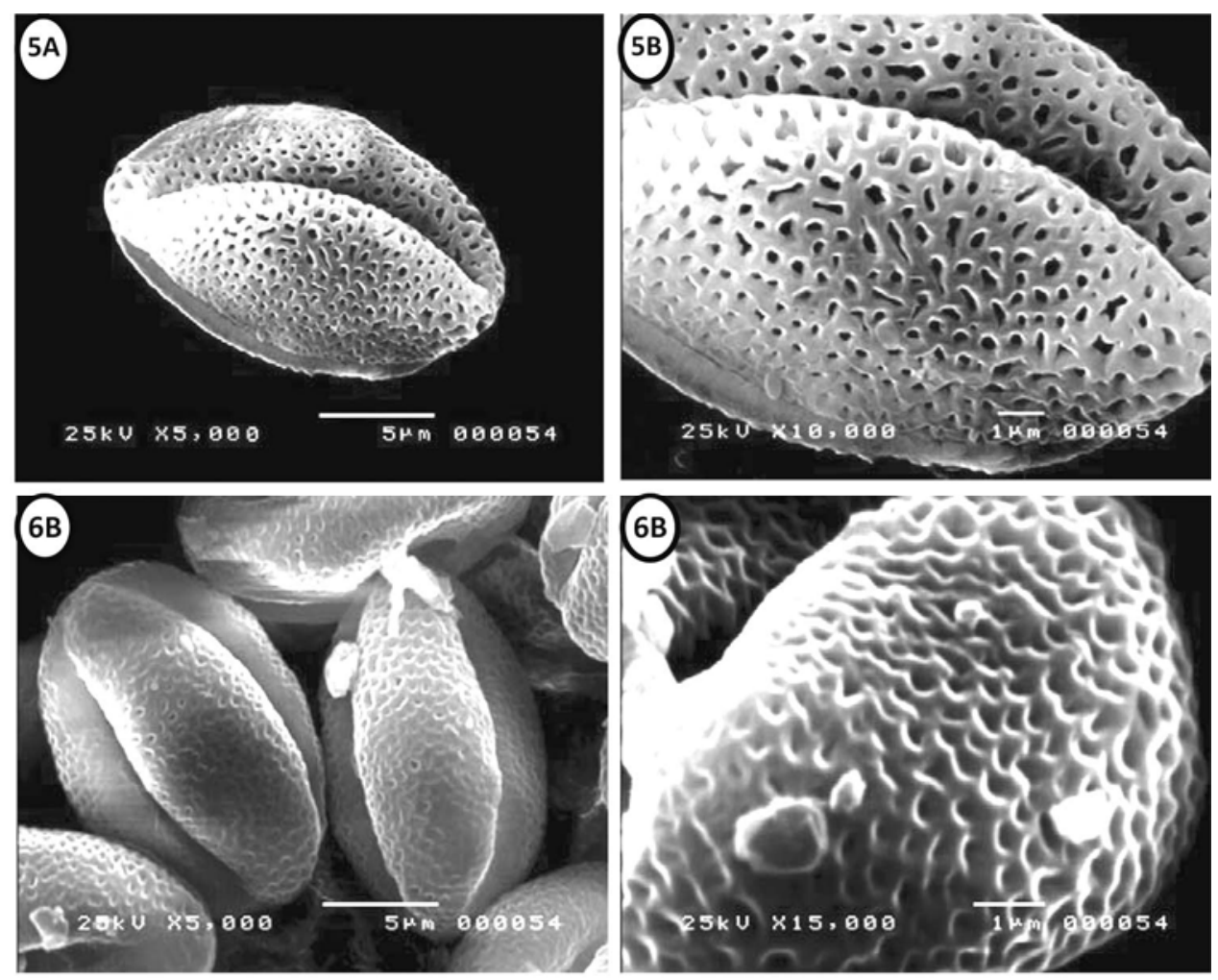

Figs 5-6. Pollen grains photographs of studied species under Scanning electron microscope: A- entire pollen grains; B - enlargement part of pollen grain exine: 5. T. passerinoides, 6. T. macrocarpa.

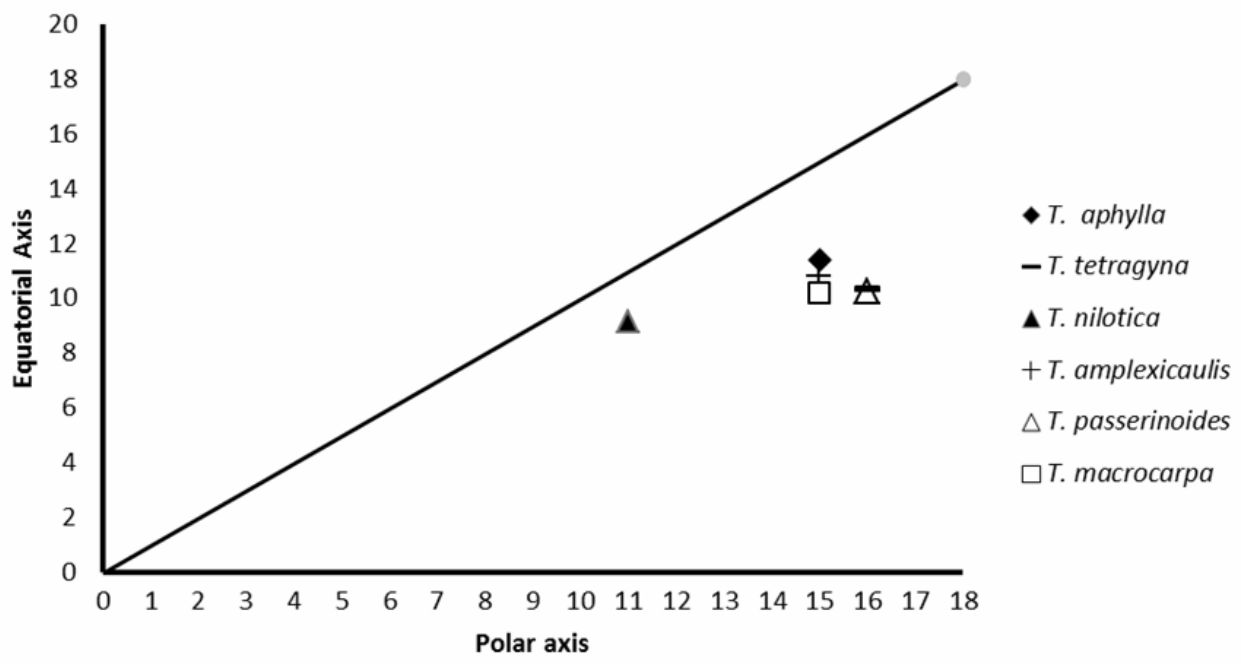

Fig. 7. Pollen mean equatorial vs. polar measurements. 
Principal components analysis (PCO)

The plot of 6 OTU's on the first three principal components is shown in Figs 9 and 10. These components interpret $87.788 \%$ of the total observed variation.

On the first component (44.523\% of the total variation in Figs. 9 and 10) a segregation is demonstrated between two groups. 1) T. amplexicaulis, T. passerinoides and T. macrocarpa; 2) $T$. nilotica, T. tetragyna and T. aphylla.

\section{Multivariate analysis of 33 morphological characters}

Cluster analysis

Figure 8 shows the dendrogram of all OTUs studied, clustered by the UPGMA method. The cophenetic correlation of distance matrix and tree matrix was 0.9512, indicating a good fit of the dendrogram to the distance matrix, see Rohlf (1990) .

Two clades were identified, namely clade A and Clade. Clade A is divided into two subgroups: subgroup (I) comprising T. amplexicaulis, and subgroup (II) comprising $T$. passerinoides and T. macrocarpa. Clade B is also divided into two subgroups: subgroup (III) comprising T. nilotica and T. tetragyna, while sub group (IV) comprising only T. aphylla.

Principal components analysis (PCO)

The plot of 6 OTU's on the first three principal components is shown in Figs 9 and 10. These components interpret $87.788 \%$ of the total observed variation.

On the first component (44.523\% of the total variation in Figs. 9 and 10) a segregation is demonstrated between two groups. 1) T. amplexicaulis, T. passerinoides and T. macrocarpa; 2) $T$. nilotica, T. tetragyna and T. aphylla.

The main characters explaining this separation (characters with high factor loading 0.6 ) are Life cycle, Color of plant bark, Leaf shape, Leaf base, Leaf apex, Inflorescence type, Inflorescence length, Bract apex, Sepal length, Sepal shape, Petal length, Petal colour, Stamen number, Disc presence, filament attachment position to the androecial disk, Style number, Capsule length, Capsule shape, Seed length and Seed shape.

The second (28.688\% of the total variation in Figs $9 \& 10)$ and third components (14.577\% of the total variation) do not reveal a divide between studied groups of the OTU's.

Table 3. List of OTU's for the Tamarix species used for the studies arranged by section and series according to Baum (1978).

\begin{tabular}{cllcl}
\hline No. & Taxon & Origin & $\begin{array}{c}\text { No. of } \\
\text { individuals }\end{array}$ & Baum (1978) \\
\hline 1. & T. aphylla & Egypt & 10 & $\begin{array}{l}\text { Section: Tamarix } \\
\text { Series: Vagianates }\end{array}$ \\
2. & T. tetragyna & Egypt, Israel & 4 & $\begin{array}{l}\text { Section: Oligadenia } \\
\text { Series: Anisandrae }\end{array}$ \\
3. & T. nilotica & Egypt & 15 & $\begin{array}{l}\text { Section: Tamarix } \\
\text { Series: Leptostachyae } \\
\text { 4. }\end{array}$ \\
T. amplexicaulis & Tunisia & 5 & $\begin{array}{l}\text { Section: Polyadenia } \\
\text { Series: Pleiandrae } \\
\text { Section: Polyadenia } \\
\text { Series: Pleiandrae }\end{array}$ \\
6. & T. masserinoides & Egypt & 3 & $\begin{array}{l}\text { Section: Polyadenia } \\
\text { Series: Pleiandrae }\end{array}$ \\
\hline
\end{tabular}


Table 4. Characters and character states used in morphometric analysis of the genus Tamarix in Egypt.

\begin{tabular}{|c|c|}
\hline Characters & Character states \\
\hline \multirow[t]{2}{*}{ 1. Life cycle } & 1. Shrubs \\
\hline & 2. Trees \\
\hline \multirow[t]{3}{*}{ 2. Plant height } & 1. $1-5 \mathrm{~m}$ \\
\hline & 2. $5-12 \mathrm{~m}$ \\
\hline & 1. Glabrous \\
\hline \multirow[t]{2}{*}{ 3. Stem indumentum } & 2. Papillose \\
\hline & 3. Papillose to glabrous \\
\hline \multirow[t]{3}{*}{ 4. Color of plant bark } & 1. Reddish brown \\
\hline & 2. Purple to dark brown \\
\hline & 1. Sheath-like \\
\hline \multirow[t]{4}{*}{ 5. Leaf shape } & 2. Oblong-lanceolate \\
\hline & 3. Ovate-deltoid \\
\hline & 4. Ovate-deltoid to lanceolate \\
\hline & 5. Amplexicaul \\
\hline \multirow[t]{3}{*}{ 6. Leaf length } & 1. $1-3 \mathrm{~mm}$ \\
\hline & 2. $3-6 \mathrm{~mm}$ \\
\hline & 1. Sessile \\
\hline \multirow[t]{3}{*}{ 7. Leaf base } & 2. Cordate and clasping \\
\hline & 3. Amplexicaul \\
\hline & 1. Acute \\
\hline \multirow[t]{3}{*}{ 8. Leaf apex } & 2. Acute to acuminate and not spreading \\
\hline & 3. Acute to acuminate and spreading \\
\hline & 4. Short pointed apex \\
\hline \multirow[t]{4}{*}{ 9. Inflorescence type } & 1. Raceme \\
\hline & 2. Simple compact spike \\
\hline & 3. Paniculate \\
\hline & 4. Simple raceme or paniculate \\
\hline \multirow[t]{2}{*}{ 10. Inflorescence length } & 1. $3-5 \mathrm{~cm}$ \\
\hline & 2. $5-10 \mathrm{~cm}$ \\
\hline \multirow[t]{2}{*}{ 11. Inflorescence width } & 1. $0.3-0.8 \mathrm{~cm}$ \\
\hline & 2. $0.8-1.2 \mathrm{~cm}$ \\
\hline \multirow[t]{2}{*}{ 12. Bract length } & 1. $1-2 \mathrm{~mm}$ \\
\hline & 2. $2-3.5 \mathrm{~mm}$ \\
\hline \multirow[t]{5}{*}{ 13. Bract shape } & 1. Ovate-deltoid \\
\hline & 2. Triangular \\
\hline & 3. Narrowly triangular \\
\hline & 4. Oblong-linear \\
\hline & 1. Acute \\
\hline \multirow[t]{3}{*}{ 14. Bract apex } & 2. Acuminate \\
\hline & 3. Upper acuminate, lower obtuse \\
\hline & $1.0 \mathrm{~mm}$ \\
\hline \multirow[t]{2}{*}{ 15. Pedicel length } & 2. $0.5-1 \mathrm{~mm}$ \\
\hline & 3. $1-1.5 \mathrm{~mm}$ \\
\hline \multirow[t]{2}{*}{ 16. Flower diamter } & 1. $2-4 \mathrm{~mm}$ \\
\hline & 2. $5-6 \mathrm{~mm}$ \\
\hline \multirow[t]{2}{*}{ 17. Sepal length } & 1. $1-1.5$ \\
\hline & 2. $1.5-2$ \\
\hline
\end{tabular}


Table 4 contd.

\begin{tabular}{|c|c|}
\hline Characters & Character states \\
\hline \multirow{5}{*}{ 18. Sepal shape } & 1. Ovate \\
\hline & 2. Broadly ovate \\
\hline & 3. Deltoid-ovate \\
\hline & 4. Ovate-elliptic \\
\hline & $\begin{array}{l}5 \text {. Outer } 2 \text { smaller and broadly ovate to } \\
\text { broadly elliptical, the inner larger, broadly } \\
\text { elliptical to suborbicular }\end{array}$ \\
\hline \multirow[t]{3}{*}{ 19. Sepal apex } & 1. Acute \\
\hline & 2. Obtuse \\
\hline & 3. Outer 2 acute, the inner obtuse \\
\hline \multirow[t]{5}{*}{ 20. Petal shape } & 1. Oblong elliptic \\
\hline & 2. Ovate elliptic \\
\hline & 3. Obovate elliptic \\
\hline & 4. Broadly elliptic to ovate \\
\hline & 5. Oblong, elliptical-oblong to obovate \\
\hline \multirow[t]{3}{*}{ 21. Petal length } & 1. $1.5-3.0 \mathrm{~mm}$ \\
\hline & 2. $3.0-4.5 \mathrm{~mm}$ \\
\hline & 1. White \\
\hline \multirow[t]{3}{*}{ 22. Petal colour } & 2. Pinkish \\
\hline & 3. Pink \\
\hline & 1. 4-5 \\
\hline \multirow[t]{2}{*}{ 23. Stamen number } & 2. $6-10$ \\
\hline & 3. $10-13$ \\
\hline \multirow[t]{2}{*}{ 24. Disc presence } & 1. Present \\
\hline & 2. Absent \\
\hline \multirow{4}{*}{$\begin{array}{l}\text { 25. Position of filament insertion } \\
\text { on the androecial disk }\end{array}$} & 1. Filament not arising from disc \\
\hline & 2. Jointed with the deep sinuses of the disc \\
\hline & 3. Inserted at the entire or retuse disc lobes \\
\hline & 4. Exserted, inserted in the sinuses of the disc \\
\hline \multirow[t]{2}{*}{ 26. Style no. } & 1.3 \\
\hline & 2. 4 \\
\hline \multirow[t]{2}{*}{ 27. Capsule length } & 1. $3-6 \mathrm{~mm}$ \\
\hline & 2. $6-13 \mathrm{~mm}$ \\
\hline \multirow[t]{4}{*}{ 28. Capsule shape } & 1. Pyriform \\
\hline & 2. Pyramidal \\
\hline & 3- Pyramidal with 4-valved \\
\hline & 4- Ovoid pyramidal \\
\hline \multirow[t]{2}{*}{ 29. Seed length } & $1.0 .5 \mathrm{~mm}$ \\
\hline & 2. $1-1.5 \mathrm{~mm}$ \\
\hline \multirow[t]{4}{*}{ 30. Seed shape } & 1. Oblong \\
\hline & 2. Ovoid oblong \\
\hline & 3. Terete \\
\hline & 4. Cylindrical \\
\hline \multirow[t]{2}{*}{ 31. Pollen shape } & 1. Prolate \\
\hline & 2. Subprolate \\
\hline \multirow[t]{2}{*}{ 32. Mean of polar axis } & 1. 11.96 \\
\hline & 2. $15.54-16.84$ \\
\hline \multirow[t]{2}{*}{ 33. Mean of equatorial axis } & 1. 9.14 \\
\hline & 2. $10.23-11.41$ \\
\hline
\end{tabular}




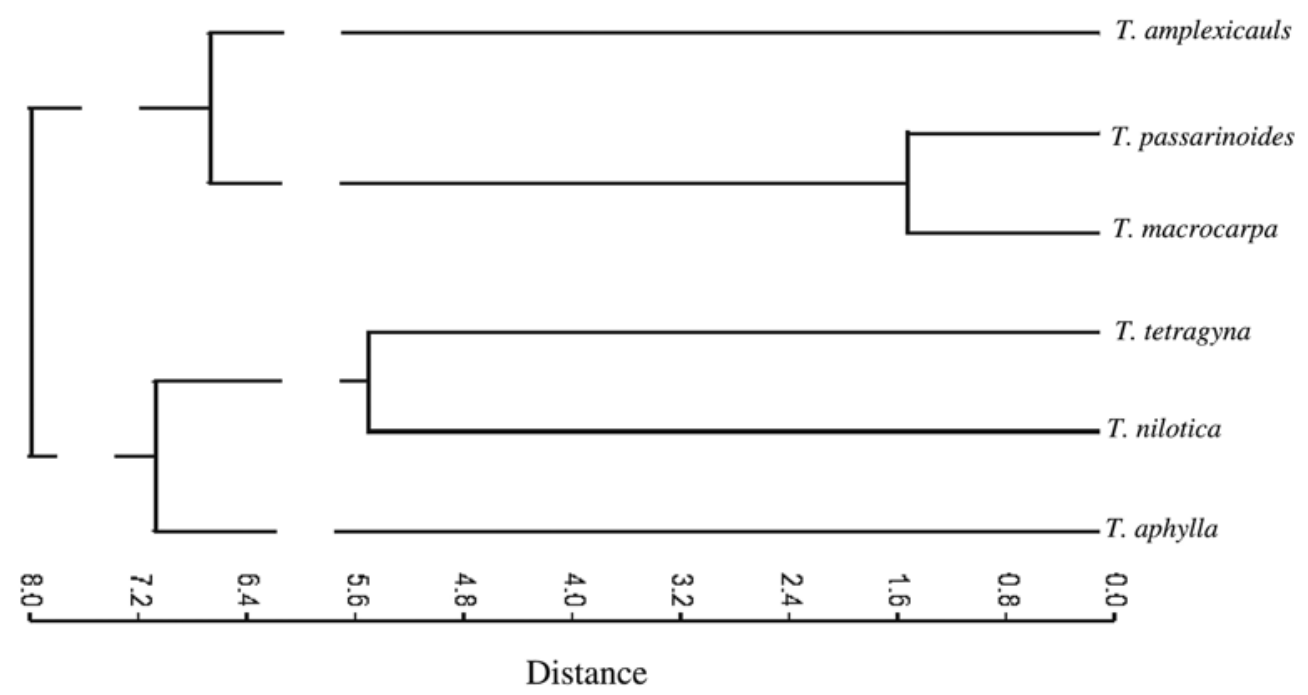

Fig. 8. UPGMA dendrogram of Tamarix speies showing interspecific relationship.method.

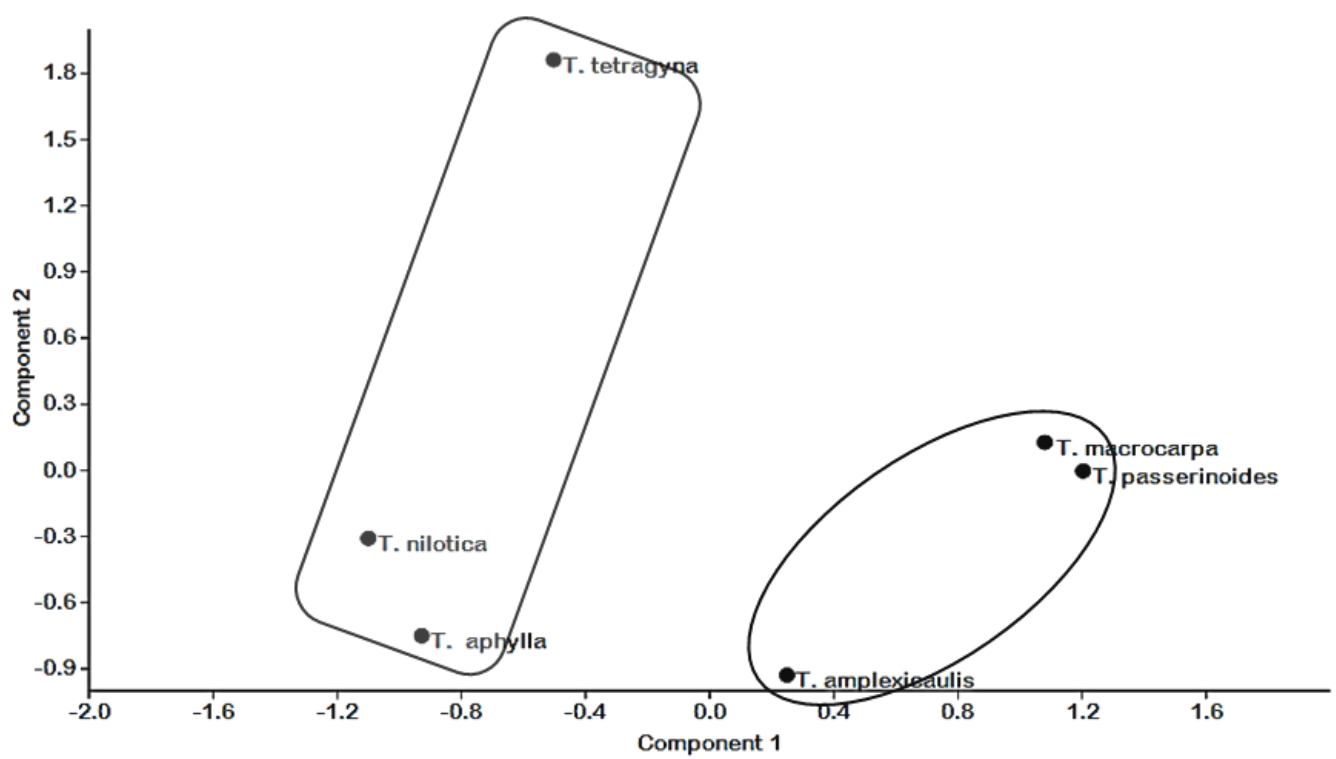

Fig.9. Scatter plot of the 6 OTUs plotted against the first principal component by the second principal component in Tamarix species. 
Table 5. Vegetative and floral characters on the first three Principal coordinates axes showing highest factor loading. Factor loading values $\geq \pm 0.6$ are shaded.

\begin{tabular}{|c|c|c|c|c|}
\hline \multirow[t]{3}{*}{ No. } & \multirow[t]{3}{*}{ Characters } & \multicolumn{3}{|c|}{ Principal components } \\
\hline & & PC 1 & PC 2 & PC 3 \\
\hline & & \multicolumn{3}{|c|}{ Factor loading } \\
\hline 1. & Life cycle & -0.7856 & -0.4095 & -0.062791 \\
\hline 2. & Plant height & -0.45467 & -0.36715 & 0.72195 \\
\hline 3. & Stem indumentum & -0.20668 & 0.72258 & -0.62667 \\
\hline 4. & Color of plant bark & 0.64978 & 0.72503 & 0.043484 \\
\hline 5. & Leaf shape & 0.71333 & -0.051789 & -0.66075 \\
\hline 6. & Leaf length & -0.2465 & 0.91203 & 0.17145 \\
\hline 7. & Leaf base & 0.9793 & -0.13841 & -0.085181 \\
\hline 8. & Leaf apex & -0.66548 & -0.43643 & 0.5511 \\
\hline 9. & Inflorescence type & 0.7604 & -0.29822 & 0.33339 \\
\hline 10. & Inflorescence length & -0.9244 & 0.2937 & 0.068594 \\
\hline 11. & Inflorescence width & -0.2465 & 0.91203 & 0.17145 \\
\hline 12. & Bract length & -0.2465 & 0.91203 & 0.17145 \\
\hline 13. & Bract shape & -0.45615 & 0.84115 & -0.18956 \\
\hline 14. & Bract apex & -0.74335 & 0.65303 & 0.13174 \\
\hline 15. & Pedicel length & 0.37491 & 0.71374 & 0.018628 \\
\hline 16. & Flower diamter & -0.2465 & 0.91203 & 0.17145 \\
\hline 17. & Sepal length & 0.64978 & 0.72503 & 0.043484 \\
\hline 18. & Sepal shape & -0.69836 & 0.28471 & 0.4677 \\
\hline 19. & Sepal apex & -0.51942 & 0.74201 & 0.11933 \\
\hline 20. & Petal shape & 0.13981 & 0.10727 & 0.57966 \\
\hline 21. & Petal length & 0.64978 & 0.72503 & 0.043484 \\
\hline 22. & Petal colour & 0.73988 & -0.10203 & 0.20584 \\
\hline 23. & Stamen number & 0.91476 & -0.19773 & -0.08085 \\
\hline 24. & Disc presence & 0.9244 & -0.2937 & -0.068594 \\
\hline 25. & $\begin{array}{l}\text { Position of filament insertion on } \\
\text { the androecial disk }\end{array}$ & -0.82778 & 0.32416 & -0.43225 \\
\hline 26. & Style number & 0.92759 & 0.051465 & -0.0052335 \\
\hline 27. & Capsule length & 0.88406 & 0.047996 & -0.089424 \\
\hline 28. & Capsule shape & 0.82411 & 0.47214 & -0.26183 \\
\hline 29. & Seed length & 0.7856 & 0.4095 & 0.062791 \\
\hline 30. & Seed shape & -0.74882 & -0.59962 & 0.18855 \\
\hline 31. & Pollen shape & -0.53904 & -0.15084 & -0.80138 \\
\hline 32. & Mean of polar Axis & 0.53904 & 0.15084 & 0.80138 \\
\hline \multirow[t]{2}{*}{33.} & Mean of Equatorial axis & 0.53904 & 0.15084 & 0.80138 \\
\hline & Percentage per PCO & 44.523 & 28.688 & 14.577 \\
\hline
\end{tabular}

Percentage total variation for the first three principal components is $87.788 \%$ 


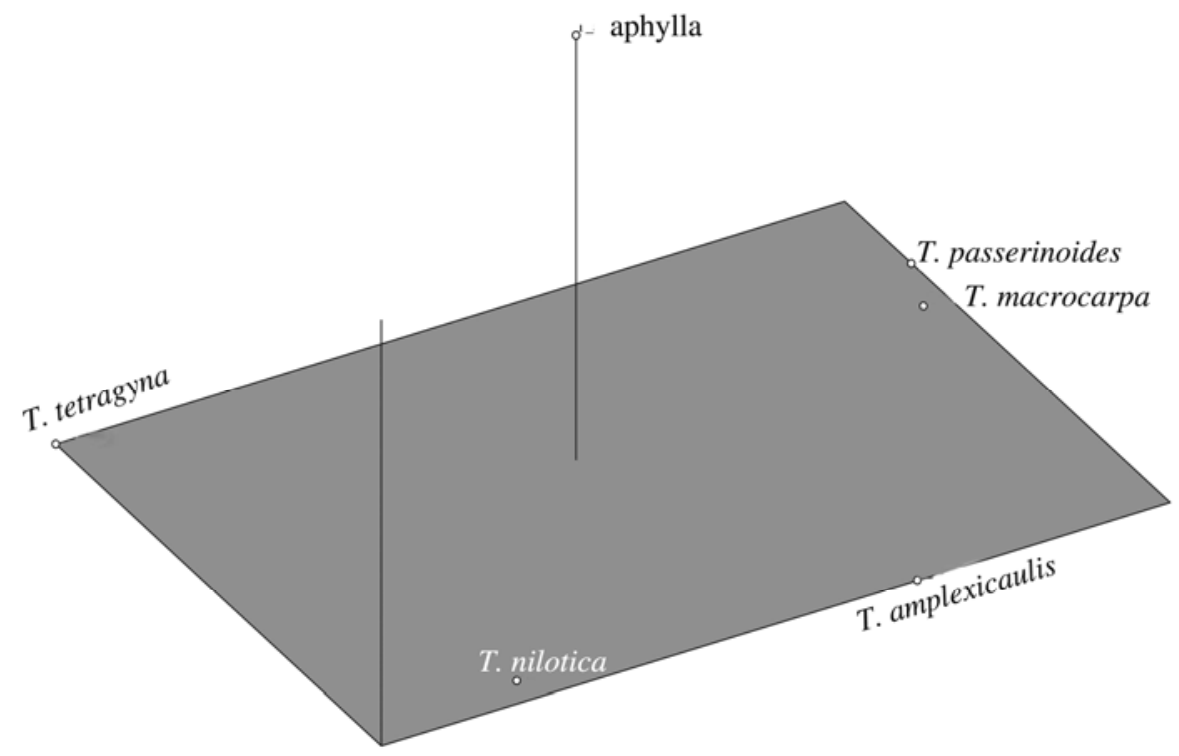

Fig. 10. Principal component analysis of Tamarix species explaining $87.788 \%$ of the variation.

\section{Discussion}

Tamarix is known as a stenopalynous genus. The morphology of pollen grains is remarkably similar, especially together with the aspects of small tricolpate and reticulate tectum. These results show congruence with those of Gaskin et al. (2004) who showed that the genus Tamarix is a monophyletic group based on data from the nuclear ribosomal region $18 \mathrm{~S}$ and chloroplast regions $r b c \mathrm{~L}$ and trnA Ser (GCU)/ trnA Gly (UCC). The pollen grains shape is either prolate or subprolate; they are subprolate in only T. nilotica (Fig. $3 \mathrm{~A}$ ), and prolate in the remaining species (Figa 1A-6A). These results agree with those of Baum et al. (1970).

The size of pollen grains overlaps for most of studied species, although $T$. nilotica is easily distinguished by their relatively small grains, against the rest of the species. The number of apertures is commonly 3, and this agree with the results of Baum et al. (1970). The ornamentation pattern of exine was found to be reticulate (Figs 1B-6B).

Morphological characters play an important role in taxonomy and to circumscribe taxa. Taxonomical problems appear when taxa show a huge amount of variability, due to ecological niches and phenotypic plasticity (Van den Berg and Groendijk Wilders, 1999).

Baum (1978) divided the genus Tamarix into Sections and Series (Table 1). Baum's study was based on a small number of morphological characters, either vegetative or floral such as the number of stamen, the length of petal, shape of androecial disk, and position of filament insertion on the androecial disk. In our present work, nearly all characters were scored and numerical methods (UPGMA and PCO) were applied to demonstrate the relationships between studied taxa and approximate the grade of variation among taxa. UPGMA analysis gives insight into degree of similarity among the OTU's and whether they form groups/clusters. PCO analysis reflects which characters are important on the axes, and indicates the significant characters based on the highest factor loading (Table 5). 
Therefore it becomes clear which characters cause the separation between groups and can be useful to distinguish taxa. In general, the results display congruence between the UPGMA clustering and PCO analyses; two major clades were identified which have been given the names of A and B. Clade A included T. amplexicaulis, T. passerinoides and T. macrocarpa. Baum (1978) placed these species in Section Polyadenia series Pleiandrae. The results obtained from both UPGMA and PCO analysis confirmed that, the group of T. amplexicaulis, T. passerinoides and $T$. macrocarpa is a well-distinguished group characterized by amplexicaul or sessile leaves with auriculate bases, racemes 6-10 (-15) mm broad, pentamerous, stamens 6-15 (mostly 10), of these 5 antesepalous and with slightly longer filaments and androecial disc with no nectariferous lobes. Our results are congruent with that of Baum (1978).

Clade B included three species, T. aphylla and T. nilotica of section Tamarix series Vagianates and Leptostachyae respectively and $T$. tetragyna of section Oligadenia series Anisandrae. The results of both UPGMA and PCO confirmed that the group of T. aphylla, T. nilotica and T. tetragyna is a well-distinguished group with racemes $3-5 \mathrm{~mm}$ broad or in dioecious trees 5-7 mm broad, petals 1.0- $2.25 \mathrm{~mm}$ long, stamens usually 5 (antesepalous) and disc various. Baum (1978) placed T. aphylla and T. nilotica in section Tamarix, and T. tetragyna in section Oligadenia. Moreover, our results placed T. nilotica closer to T. tetragyna than to T. aphylla, which is contrary to Baum's sections. Arianmanesh et al. (2015) presented a phylogenetic analysis based on internal transcribed spacer (ITS) of 15 Tamarix samples recognized by recent taxonomic treatments from Iran. In addition, 19 previously ITS sequences from GenBank were used. The results of data analysis indicated that, the classification of the genus Tamarix into three sections based on some morphological characters by Baum (1978) is not supported by that molecular analyses as well as the classification of species according to the morphology of androecial disc, but the morphology of leaf and number of flower parts are useful for the classification and identification of Tamarix species. Both of morphological characteristics and molecular data will be most effective to determine the evolution of the genus Tamarix.

According to Arianmanesh et al. (2015), two main clades were found; Clade (B) included $T$. nilotica, T. passerinoides T. tetragyna var. meyeri and T. aphylla and clade (C) included $T$. amplexicaulis and T. tetragyna var. deserti. Our results are in matching with those of Arianmanesh et al. (2015), in which they support the presence of T. nilotica, T. tetragyna and T. aphylla in one section, and T. amplexicaulis in other section, and disagree with those of Baum (1978).

Our results using the UPGMA and PCO analysis to show the similarities between species indicate that there is some degree of similarity between the species of section Polyadenia.

\section{Acknowledgements}

We are grateful to the Directors and Curators of Naturhistorisches Museum Wien (Vienna) Herbarium (W), Kew Herbarium (K), Leiden Herbarium (L) Wageningen University Herbarium (WAG), Cairo University Herbarium (CAI), Agriculture Museum in Dokki (CAIM), and Assiut University Herbarium (ASTU) for the loan of specimens. Our great thanks are due to Dr. John Gaskin; Botanist/Research Leader PMRU, USDA ARS NPARL. Sidney, USA for going through the manuscript and making valuable suggestions.

\section{References}

Arianmanesh, R., Mehregan, I., Nejadsatari, T., Assadi and M. 2015. Molecular phylogeny of Tamarix (Tamaricaceae) species from Iran based on ITS sequence data. Eur. J. Exp. Biol. 5: 44-50.

Baum, B. 1978. The genus Tamarix. Israel Academy of Sciences and Humanities. 
Baum, B., Bassett, I. and Crompton, C. 1970. Pollen morphology and its relationships to taxonomy and distribution of Tamarix, series Vaginantes. Österreichische Botanische Zeitschrift 118: 182-188.

Boulos, L. 2000. Flora of Egypt (Geraniaceae- Boraginaceae). Al Hadara Publishing, Egypt, pp. 124-130.

Bunge, A.G.V. 1852. Tentamen generis Tamaricum species accuratius definiendi. Dorpati: ex Officina Academica viduae JC Schuenmanni et C. Mattieseni.

Crins, W. 1989. The Tamaricaceae in the southeastern United States. J. Arnold Arboretum 70: 403-405.

Erdtman, G. 2013. An Introduction to Pollen Analysis. Read Books Ltd.

Gaskin, J.F. and Schaal, B.A. 2003. Molecular phylogenetic investigation of US invasive Tamarix. Systematic Botany 28: 86-95.

Gaskin, J.F., Ghahremani-nejad, F., Zhang, D.Y. and Londo, J.P. 2004. A systematic overview of Frankeniaceae and Tamaricaceae from nuclear rDNA and plastid sequence data. Ann. Miss. Bot. Gard. 91: 401-409.

Hammer, Ø., Harper, D.A.T., and Ryan, P. D. 2001. PAST: Paleontological Statistics Software Package for Education and Data Analysis. Palaeontologia Electronica 4 (1): pp. 9. Available at: http://folk.uio.no/ohammer/past/.

Hosni, H. A. 2000. Tamaricaceae in the flora of Egypt. Taeckholmia 20: 17-31.

Huysmans, S., Dessein, S., Smets, E. and Robbrecht, E. 2003. Pollen morphology of NW European representatives confirms monophyly of Rubieae (Rubiaceae). Rev. Palaeobot. and Palynol. 127: 219240.

Moore, P., Webb, J. and Collinson, M. 1991. Pollen Analysis, 2nd. Blackwell, Oxford.

Punt, W., Hoen, P., Blackmore, S., Nilsson, S., Le Thomas, A. 2007. Glossary of pollen and spore terminology. Rev. Palaeobot. and Palynol. 143: 1-81.

Rusanov, F. 1949. Sredniyeaziatskie Tamariksi. Tash-kent.[Tamarisks of Central Asia.].

Täckholm, V. 1974. Students' Flora of Egypt. Cairo University, Egypt.pp. 366-369.

Van den Berg, R.G. and Groendijk Wilders, N. 1999. Numerical analysis of the taxa of series Circaeifolia (Solanum sect. Petota). Solanaceae IV: advances in biology and utilization. Kew: The Royal Botanic Gardens, Kew,pp. 213-226.

Venturella, G., Baum, B. and Mandracchia, G. 2007. The genus Tamarix (Tamaricaceae) in Sicily: first contribution. Flora mediterranea 17: 25-46.

Villar, J.L., Alonso, M.Á., Vicente, A., Juan, A. and Crespo, M.B. 2014. The genus Tamarix (Tamaricaceae) in Crete (Greece). Willdenowia 44: 321-326.

Wieringa, J.J. 1999. Monopetalanthus exit. A systematic study of Aphanocalyx, Bikinia, Icuria, Michelsonia and Tetraberlinia (Leguminosae,Caesalpinioideae). Wageningen Agricultural University, Wageningen, Netherlands, pp. 320.

Wilken, D.H. 1993. Tamaricaceae. In: Hickman, J.C. (Ed.), The Jepson Manual: Higher Plants of California University of California Press, Berkeley, Los Angeles, London, pp. 1080.

Zohary, M. 1972. Tamarix. In: Zohary, M. and Feinbrun-Dothan, N.( Eds.), Flora Palaestina, Vol. 2. Israel Academy of Sciences and Humanities, Jerusalem, pp. 351-364.

(Manuscript received on 16 November 2016; revised on 26 March 2017) 
Appendix 1. List of pollen grain specimens used in the study of genus Tamarix L. by means of light and scanning electron microscope (SEM).

\begin{tabular}{llll}
\hline Sl.No. & Species & Locality & Vouchers \\
\hline 1. & Tamarix aphylla (L) H. Karst. & Egypt, Sinai, Musa & F. J. Breteler 15819, \\
& & well & 26.02.2002 \\
2. & Tamarix tetragyna Ehrenb. & $\begin{array}{l}\text { Israel, Negev, Revivim, } \\
\text { ditches }\end{array}$ & $\begin{array}{l}\text { J. D. Angelis 552, } \\
\text { 22.03.1952 }\end{array}$ \\
3. & Tamarix nilotica (Ehrenb.) Bunge & Egypt, 10 km N. & A. M. Cleef s.n., \\
& & Hurghada & 36.09.2009 \\
4. & Tamarix amplexicaulis Ehrenb. & Tunisia, Bordj El & P. Goelghebeur 3030, \\
& & Khadra & 06.09.1979 \\
5. & Tamarix passerinoides Delil ex Desv & Egypt, Fayum & Kralik, s.n. 14.03. 1848 \\
6. & Tamarix macrocarpa (Ehrenb.) Bunge & Herbarium accession & W 1889. 0320243. \\
& & number & (Vienna) \\
\hline
\end{tabular}

